\title{
Type Specimens and Scientific Memory
}

\section{Lorraine Daston}

\begin{abstract}
Now the whole earth had one language and few words. And as men migrated in the east, they found a plain in the land of Shinar and settled there. And they said to one another, "Come, let us make bricks, and burn them thoroughly." And they had brick for stone, and bitumen for mortar. Then they said, "Come, let us build ourselves a city, and a tower with its top in the heavens, and let us make a name for ourselves, lest we be scattered abroad upon the face of the whole earth.” And the Lord came down to see the city and the tower, which the sons of men had built. And the Lord said, "Behold, they are one people, and they have all one language; and this is only the beginning of what they will do; and nothing that they propose to do will now be impossible for them. Come, let us go down, and there confuse their language, that they may not understand one another's speech." So the Lord scattered them abroad from there over the face of all the earth, and they left off building the city. Therefore its name was called Babel, because there the Lord confused the language of all the earth; and from there the Lord scattered them abroad over the face of all the earth.
\end{abstract}

-Genesis, 11:1-9

\section{After Babel}

Botany is the science that strives to undo the mischief of Babel. Botanists have no interest in restoring the purity of the prelapsarian language of paradise, in which Adam called the beasts of the field and the fowl of the air and presumably also the plants of the meadow "by their own names," those proper to them in the deepest possible sense. ${ }^{1}$ They are untroubled by the yawning gap between word and thing and the conventionalism of linguistic signs. It is true that, since at least the eighteenth century, botanists have repeatedly tried to dictate the right way to name a plant; the great Swedish botanist Carlolus von Linnaeus, for example, discouraged all metaphors and irony and permitted analogies to human body parts only if these were external or well known to everyone (so Fungus penis, but not Orchis fallopiana). ${ }^{2}$ Nineteenth-century botanists for their part found many Linnaean names fanciful or indelicate and set down their own rules, such as don't name genera after people who have nothing to do with botany; use names

Unless otherwise specified, all translations are my own. My thanks to Benjamin Kristek for research assistance, to Jean-Marc Drouin for an enlightening conversation, and to Abigail Lustig and Staffan Müller-Wille for perspicacious comments.

1. See Umberto Eco, "Languages in Paradise," Serendipities: Language and Lunacy, trans. William Weaver (New York, 1998), p. 23.

2. See Carlolus von Linnaeus, Critica botanica (1737), trans. Arthur Hort and M. L. Green (London, 1938), aphorisms 296, 299, pp. 177, 182; hereafter abbreviated CB.

Critical Inquiry 31 (Autumn 2004)

(C) 2004 by The University of Chicago. 0093-1896/04/3101-0004\$10.00. All rights reserved. 
derived from "barbarous languages" only if they are "easily adapted to the Latin language and to the languages of civilized countries." 3 But once a name, however vulgar or obscure or downright misleading, has been attached by botanical tradition, it can be changed only for the weightiest of reasons. ${ }^{4}$ Natural historical nomenclature is a convention that aspires to the permanence of nature itself.

What botanists fear is not convention but the proliferation of many names for the same plant species, genus, or other taxon, a confusion of language for which the technical term is synonymy. The curse of Babel was visited upon them rather late, at least by the standards of Genesis; only in the late eighteenth and early nineteenth centuries did botanists begin to complain about the multiplication of names for the same entity. By the $1860 \mathrm{~s}$ anxiety over galloping synonymy (10o new genera had, for example, yielded 117 synonyms [see $L$, p. 8] $)^{5}$ galvanized botanists into action, and in 1867 they instituted a long and still ongoing series of international codes of nomenclature, named for the cities-Paris, Vienna, Tokyo, Saint Louis-in which they were hammered out, sometimes amidst loud controversy. These codes sought and still seek to stabilize the names of plants, to re-create the "one language and few words" of the time before God put a stop to tower building in the plain of Shinar. At stake was the continuity of botanical knowledge over centuries and continents. This is why Jean-Jacques Rousseau, an avid botanist in later life, railed against opponents of Linnaean nomenclature, although he himself entertained doubts about the Linnaean system of classification:

3. Alphonse de Candolle, Lois de la nomenclature botanique (Paris, 1867), art. 28.4-5, p. 20; hereafter abbreviated $L$.

4. As the 1999 International Code of Botantical Nomenclature (Saint Louis Code) states in its preamble, "This Code aims at the provision of a stable method of naming taxonomic groups, avoiding and rejecting the use of names which may cause error or ambiguity or throw science into confusion. Next in importance is the avoidance of the useless creation of names." Even names defined as illegitimate by the rules may be conserved (nomina conservanda) to "avoid disadvantageous nomenclatural changes" (International Code of Botantical Nomenclature [Saint Louis Code], ed. W. Greuter et al., http://www.bgbm.org/IAPT/Nomenclature/Code/SaintLouis, preamble, art. 14.1; hereafter abbreviated SLC).

5. See Candolle's chart on p. 9. The example cited by Candolle was taken from George Bentham and Joseph Dalton Hooker, Genera plantarum, 3 vols. (London, 1862-83), vol. 1, fasc. 1-2.

Lor Ra ine Daston is the director at the Max Planck Institute for the History of Science, Berlin. Her recent publications include (with Katharine Park) Wonders and the Order of Nature, 1150-1750 (1998), Wunder, Beweise, und Tatsachen: Zur Geschichte der Rationalität (2001), and (coedited with Fernando Vidal) The Moral Authority of Nature (2004). 
It is a matter of whether three hundred years of study and observation must be lost to botany, whether three hundred volumes of figures and descriptions must be cast into the fire, whether the knowledge acquired by all those savants who consecrated their fortunes, their life, and their pains to vast, costly, and perilous voyages must remain useless to their successors, and whether a single person always starting from zero will be able to attain by himself the same knowledge that a long series of researches and studies have disseminated to the mass of the human species. $^{6}$

Botanical nomenclature is an art of transmission that makes a certain kind of science possible.

Clarity about just what kind of science and therefore what kind of art of transmission is in order here. We often habitually oppose the humanities to the sciences along the axis of tradition versus progress: the humanities are portrayed as conservers of texts in editions or objects in museums, guardians of living cultural memory; the sciences, by contrast, as endlessly overthrowing old theories by new, deliberate amnesiacs about any disciplinary past older than yesterday's issue of Science or Nature. But botany (like all the sciences once collectively designated as natural history) ${ }^{7}$ is both traditional and progressive, a science of museums as well as of breaking news in scientific journals. Since the sixteenth century, botanists have been drying and pressing plants between the leaves of bound volumes known as herbaria, which are carefully preserved for consultation in major research institutions such as the Muséum Nationale d'Histoire Naturelle in Paris, the Botanisches Museum in Berlin, or the Linnaean Society in London (which still holds Linnaeus's own collection). Like art historians writing a monograph on van Eyck or Cézanne who travel to the museums holding original paintings, botanists travel to the herbaria containing the ur-spec-

6. Jean-Jacques Rousseau, "Fragmens pour un dictionnaire des termes d'usage en botanique" (1781), Oeuvres complètes, ed. Bernard Gagnebin and Marcel Raymond, 5 vols. (Paris, 1999), 4:1209; quoted in Jean-Marc Drouin, "Les Herborisations d'un philosophe: Rousseau et la botanique savante," in Rousseau et les sciences, ed. Bernadette Bensaude-Vincent and Bruno Bernardi (Paris, 2003), p. 86.

7. There are many parallels between modern botanical and zoological codes of nomenclature, as a result of shared challenges and mutual influences. I have however chosen to concentrate on botany, in part because of significant divergences in practices by circa 1850 and in part because important technical advances in the preservation of specimens in botanical and zoological collections have different chronologies. On divergences, see Peter F. Stevens, "Metaphors and Typology in the Development of Botanical Systematics 1690-1960, or the Art of Putting New Wine in Old Bottles," Taxon 33 (May 1984): 169-211; on taxidermy, see Paul Lawrence Farber, "The Development of Ornithological Collections in the Late Eighteenth and Early Nineteenth Centuries and Their Relevance to the Emergence of Ornithology as a Scientific Discipline," Lournal of the Society of the Bibliography of Natural History 9, no. 4 (1980):391-94. 
imens of the species under study - the type specimens or "holotypes" to which the original description and name is anchored. Yet botany is also regularly convulsed by the Saint Vitus's dance of scientific change. The bases of classification are matters of ongoing theoretical reflection and empirical inquiry and, since the eighteenth century, have been shaken by a succession of novelties. Whether taxonomists embrace the Baupläne of morphology, the phylogenies of Darwinism, the traits of cladistics, or the genealogies of mitochondrial DNA may have potentially seismic consequences for the boundaries and interrelationships of taxa. ${ }^{8}$

The stabilization of botanical nomenclature was meant to reconcile scientific memory and amnesia. On the side of amnesia, it guaranteed neither the permanence of theories nor the finitude of discovery, though some scientists still longed for both. The mid-nineteenth-century movement to combat synonymy through elaborate codes of botanical nomenclature coincided with a more general scientific awakening to the unsettling fact that progress in their disciplines would not only be expansive, adding new territories of knowledge to domains already securely conquered, but openended and revolutionary. ${ }^{9}$ In his monumental 1844 survey of the state of the sciences, German naturalist Alexander von Humboldt reflected sadly on ephemeral science:

It has often been a discouraging consideration, that while purely literary products of intellectual activity are rooted in the depth of feelings and interwoven with the creative force of the imagination, all works treating of empirical knowledge, and of the connection of natural phenomena and physical laws are subject to the most marked modifications of form in the lapse of short periods of time, both by improvement in the instruments used, and by the consequent expansion of the field of view opened to rational observation, and that those scientific works which have, to use a common expression, become antiquated by the acquisition of new funds of knowledge, are thus continually being consigned to oblivion as unreadable. ${ }^{10}$

8. On the history of taxonomy and nomenclature in botany and zoology, see Annette Diekmann, Klassifikation—System—“scala naturae": Das Ordnen der Objekte in Naturwissenschaft und Pharmazie zwischen 1700 und 1850 (Stuttgart, 1992); Stevens, The Development of Biological Systematics: Antoine-Laurent de Jussieu, Nature, and the Natural System (New York, 1994); Richard V. Melville, Towards Stability in the Names of Animals: A History of the International Commission on Zoological Nomenclature 1895-1995 (Dorchester, 1995); Staffan Müller-Wille, Botanik und weltweiter Handel: Zur Begründung eines natürlichen Systems der Pflanzen durch Carl von Linné (1707-78) (Berlin, 1999); and Farber, Finding Order in Nature: The Naturalist Tradition from Linnaeus to E. O. Wilson (Baltimore, 2000).

9. See Lorraine Daston, "The Historicity of Science," in Historicization-Historisierung, ed. Glenn W. Most (Göttingen, 2001), pp. 201-21.

10. Alexander von Humboldt, Cosmos, trans. E. C. Otté and W. S. Dallas, 5 vols. (1844; New York, 1850-59), 1:xi-xii. 
On the side of memory, the first international codes of botanical nomenclature were explicitly formulated as responses to what Swiss botanist Alphonse de Candolle called "the continual and necessary changes in science" ( $L$, p. 11). Echoing von Humboldt's sigh over the short shelf life of scientific publications, Candolle urged his colleagues to resign themselves to the hard fact that years hence all that would endure from their lifelong work would be descriptions of plants- ${ }^{11}$ and even these would be lost if the names attached to them were allowed to proliferate or wander.

But how to turn back the chaos of Babel and insure that one and only one name was affixed to every known plant species? The interest of botanical nomenclature as an art of transmission lies not in its ends, which are to insure continuity and fixity of reference across generations and around the world, but in its means. The name of a botanical species does not inhere in the population of all members of that species, nor in some abstracted prototype or essence of the species, but rather in a single, concrete individual specimen that has been designated by the person who first publishes a newly discovered species as its holotype or type specimen, ideally for all time. ${ }^{12}$ Instead of using names to subsume particulars under what John Locke called "general ideas," the general idea, or what in logic as well as in natural history has for millennia been called the "species," has here been mapped onto a particular individual. This is a radical solution to the several problems of how to compress the many into one, to render the abstract via the concrete, and to tether words to things and hence akin to dilemmas of political representation, literary personification (or, for that matter, theological incarnation), and linguistic reference. Of course the botanists, who haltingly and heatedly debated the codes of botanical nomenclature that eventually laid down the type method for preserving the stability of names, were primarily concerned with practices, not philosophy. Yet it was precisely their gradual articulation of a set of practices (publishing, labeling, traveling, referencing, compiling) centered on a collection of objects (type specimens), that is, an art of transmission, that turned the code articles on nomenclatural types into a remarkable act of applied metaphysics, or so I shall argue.

I shall do so first by explaining what modern type specimens in botany

11. See Candolle, La Phytographie (Paris, 1880), p. xi.

12. Although I will follow general usage in referring to holotypes and type specimens interchangeably, some botanists have used the latter term to refer collectively to all the specimens used to establish a type (for example, paratype, syntype, epitype, lectotype, and so on), whereas the former term is reserved for "a single specimen (or fragment) upon which a species is based" (Donald Leslie Frizell, “Terminology of Types," American Midland Naturalist 14 [1933]: 652). See also Wörterbuch der Botanik: Die Termini in ihrem historischen Zusammenhang, ed. Gerhard Wagenitz (Jena, 1996), pp. 180, 387. 
do and how they do it. They are the foundation of a taxonomical pyramid that links the individual plant to the plant kingdom through ascending taxa of ever greater generality; each level of the hierarchy is typified by a designated representative at the next lower level: the species by the type specimen, the genus by the type species, and so on. The unbroken transmission of the names of plant species depends on this type method, which was first advanced in the late nineteenth century and only gradually adopted through a series of international codes of botanical nomenclature from 1867 to 1999 that at once dictate and reflect approved botanical practices. Some historical background, provided in the next section, of the origins of the type method is needed in order to appreciate how the modern type specimen achieved its paradoxical status as a concrete abstraction, in nearly diametrical opposition to earlier botanical conceptions and practices linking individual specimens with the type of the species. In conclusion, I return to the implications of the type specimen as a case of metaphysics in action.

\section{Type Specimens Are Not Typical}

Whereby it is evident, that the Essences of the sorts, or (if the Latin word please better) Species of Things, are nothing else but these abstract Ideas. —John Locke, An Essay Concerning Human Understanding (1690 $)^{13}$

Some of the most precious holdings of major natural history museums around the world are rarely if ever displayed to the public. These are the museums' collections of type specimens, which by edict serve as the last court of appeal in all questions and disputes about species definition, membership, and names. In a modern collection, type specimens are ordinarily flagged by a color-coded system, housed in fireproof rooms, and consulted only by specialists under the watchful eyes of curators. Should, despite these precautions, brittle specimens crumble as herbarium pages are turned and flattened for use, fragments are to be painstakingly collected and kept (fig. 1). Because botanists must return again and again to these touchstones whenever nomenclatural and classificatory questions are raised, ambitious databases like the Botanical Type Specimen Register attempt to locate and catalogue the holotypes held by public herbaria, estimated at perhaps four million specimens scattered over a thousand herbaria worldwide. ${ }^{14}$

For zoologists, such collections were first made possible by late eighteenth-and early nineteenth-century developments in taxidermy, ${ }^{15}$ but bot-

13. John Locke, An Essay Concerning Human Understanding, ed. Peter H. Nidditch (1690; Oxford, 1975), 3.3.2, p. 414.

14. See Stanwyn G. Shetler, An Introduction to the Botanical Type Specimen Register (Washington, D.C., 1973), p. 6.

15. See Farber, "The Type-Concept in Zoology during the First Half of the Nineteenth Century," Journal of the History of Biology 9 (Spring 1976): 97. 


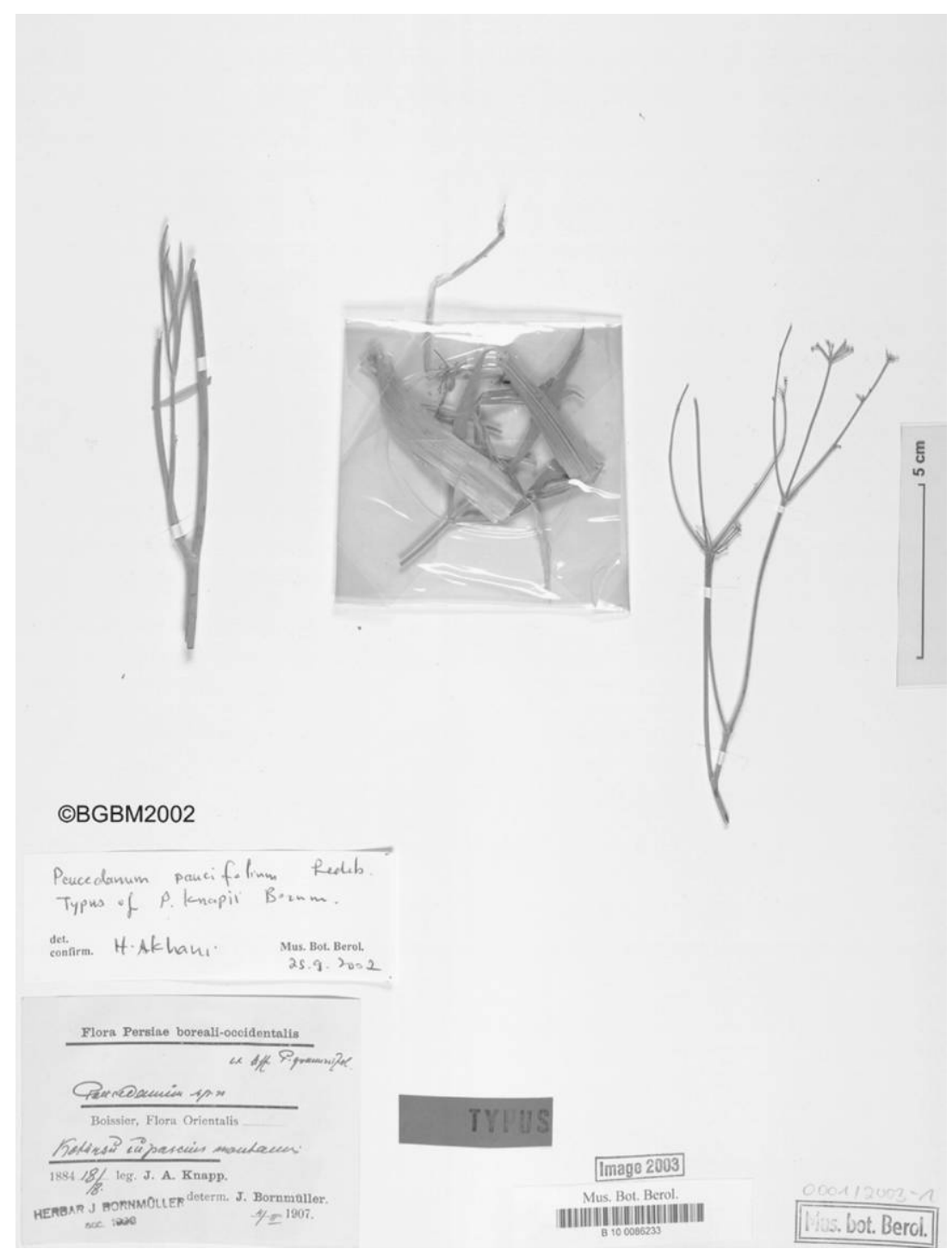

F I G U R E 1. Holotype of species Peucedanum paucifolium with fragments preserved. Courtesy of the Botanisches Museum, Berlin, B100086233. 
anists had kept herbaria—called hortus siccus, "dry" or "winter garden"since the Renaissance. ${ }^{16}$ Yet only in the late nineteenth and early twentieth centuries that did museums begin to mark, conserve, and register the type specimens, many of them already preserved for over a century but not heretofore singled out for special attention, with fastidious care. Circa 1900 admonitions begin to appear in scientific publications:

Types are the most valuable possession of museums and constantly increase in value as years elapse. They should not be left in the herbarium with the ordinary specimens, but should be so mounted as to be protected from injury in handling and should be kept in fire-proof cases, if possible in a special room where they may be consulted in the presence of a custodian who can help preserve all fragments of the type material. ${ }^{17}$

Not all type specimens are in fact actual plants, though most are. If a plant is difficult to preserve in a herbarium (or if the author of a species provides a figure but not a holotype in the original description), an illustration may become the type specimen ("iconotype") —as in the case of the Liliaceae family, which includes daffodils, hyacinths, and other plants hard to flatten onto the pages of a herbarium because of their fleshy stalks (for some of these the magnificent colored engravings of Pierre-Joseph Redouté serve as the type specimens). ${ }^{18}$ Special rules also govern fossil plant specimens, which are usually fragmentary, and microorganisms that must be preserved in cultures or on microscope slides (see SLC, art. 8.3-5). For the most part, however, type specimens are dried, flattened plants mounted on the pages of a herbarium (fig. 2). The botanists' preference for herbarium specimens over even the most faithful illustration goes back at least to Linnaeus. To the untutored eye, botanical type specimens are as unprepossessing as relics are to the nondevout; the dessicated plants have lost much of their color and form, and it takes considerable training to be able to match a herbarium specimen with the living plant observed in nature. The type specimens are nonetheless regarded as unique and irreplaceable, the ultimate guarantee of the integrity of botanical names.

16. The term herbarium was originally a book of medical plants; Joseph Tournefort applied the word to mean a hortus siccus (allegedly invented by Bologna professor Luca Ghini in the early sixteenth century) in 1700 and by the late eighteenth century herbarium had become the standard term. See William Thomas Stern, "An Introduction to the Species plantarum and Cognate Botanical Works of Carl Linnaeus," in Linnaeus, "Species plantarum": A Facsimile of the First Edition, 2 vols. (1753; London, 1957), 1:103.

17. Walter T. Swingle, “Types of Species in Botanical Taxonomy," Science, n.s., 37, no. 962 (1913): $864-65$.

18. See Pierre-Joseph Redouté, Les Liliacées, 8 vols. (Paris, 1802-16). 


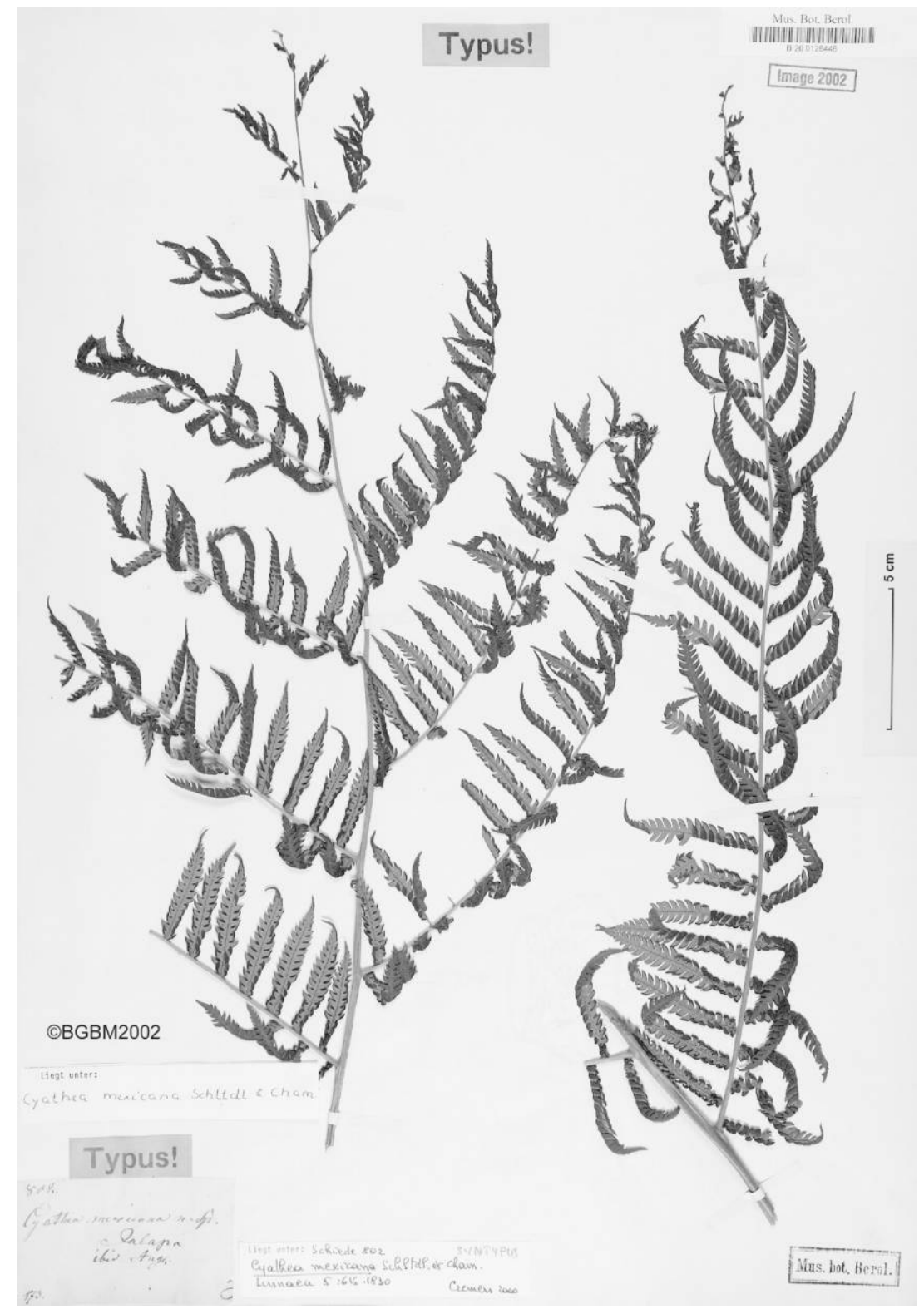

F I G U R E 2. Holotype and syntype of species Cyathea mexicana. Courtesy of the Botanisches Museum, Berlin, B200126446. 
Indeed, it is the name of the species, rather than the species itself, that is directly attached to the type specimen. Boundaries of species (and higher taxa) change with new discoveries and new classification schemes; names may not. The singularity of the type specimen safeguards the permanence of the name. And it is the priority of publication (by the author of the species) that in turn assures the strict singularity of the specimen. A luxuriant growth of terminology (lectotype, syntype, paratype, epitype, neotype) surrounds the type specimen (SLC, art. 9) ${ }^{19}$ but the root concept is that of the holotype, which bears the species name: "A holotype of a name of a species or infraspecific taxon is the one specimen or illustration used by the author, or designated by the author as the nomenclatural type. As long as a holotype is extant, it fixes the application of the name concerned" (SLC, art. 9.1).

The phrase "author of the species" sounds faintly blasphemous. Saint Thomas Aquinas (following Augustine) after all described God as the "author of nature," the drawer of species boundaries..$^{20}$ Although the theological pretensions of modern botanists are doubtless modest or nonexistent, the legislative force of botanical naming, accompanied by a description of the new entity and a designation of its type, does recall divine fiat in some of its aspects. There is even a stipulated moment of creation, when the tradition of botanical naming begins: the magisterial Species plantarum (1753) of Linnaeus, containing some six thousand names of plant species and varieties and exemplifying the system of binomial nomenclature that has since become standard. ${ }^{21}$

As in all acts of baptism, the giving of names to individuals involves a fiat, an act of will, and the will of the author is of moment in assigning a holotype. Should the author have failed to designate a holotype in the first publication (as was more the rule than the exception prior to the latter half of the nineteenth century, for reasons that are explained below), a lectotype must be selected posthumously in order to secure the name by an individual specimen. In such cases, no pains may be spared in order to divine what might have been the author's intentions in this regard. The Saint Louis Code

19. See also, for the history of this terminology, Charles Schuchert, "What Is a Type in Natural History?" Science, n.S., 5, no. 121 (1897): 636-40. At one point botanists found themselves in the absurd position of combating the synonymy of the type terminology, itself introduced to combat the synonymy of nomenclature; see Frizzell, "Terminology of Types," pp. 637-40.

20. Thomas Aquinas, Summa theologica, 5 vols. (Turin, 1922), IIa-ae, 153.12, 4:141-42; compare Augustine, Confessions, trans. R. S. Pine-Coffin (Harmondsworth, 1961), 3.8, p. 65.

21. See "The Linnaean Database," http://www.nhm.ac.uk/botany/linnaean/Introduction.html. The first edition of the Species plantarum (1753) was officially accepted as the starting point for botanical nomenclature for all groups of vascular plants at the International Botanical Congress of 1905 at Vienna; see Stern, "An Introduction to the Species plantarum and Cognate Botanical Works of Carl Linnaeus," p. 4. The starting point for zoological nomenclature is the tenth edition of Linnaeus's Systema naturae (1758). 
admonishes those charged with the choice of a lectotype to pay close attention to the author's original description, to cultivate "an understanding of the author's method of working," to take account of the fact that the relevant specimens may not be preserved in the author's own herbarium, to sift the author's "manuscript notes, annotations on herbarium sheets, recognizable figures, and epithets such as typicus, genuinus, etc." for any clue to the author's intent (SLC, art. 9.A.1-5). The author's mainmort extends even after the designation of lectotype; ordinarily, the lectotype must be followed, unless "any of the original material [used by the author] is rediscovered," in which case the author once again rules from beyond the grave (SLC, art. 9.17). No court investigates the unrecorded intentions of past legislators with more care than botanists searching for indications of an author's unpublished preferences with regard to a type specimen. Botanists may not create their species, but they author them in a strong sense, belied by the figurative but borne out by the literal sense of a "nominal author"-here, the author of a name.

This fixation on holotypes and authorial intentions is the precondition for the fixity of botanical names. A single specimen designated by a first author with an accompanying name, description, and perhaps a figure combats the scourge of synonymy-the result of multiple authors describing multiple specimens with multiple names. Since the only link between specimen, description, and name is the author, the integrity of the match among these elements depends on the coherence of the author's intent-which is hence assumed to be monolithic and declared to be almighty. The price for this coherence with respect to names and referents is a great deal of contingency elsewhere: the description may be ambiguous, the Latin binomial name may be ungrammatical or unsuitable, the figure poorly executed, and, above all, the holotype unrepresentative. The rule that the type specimen must be a single plant, gathered at a particular time and place, is especially problematic for species that are polymorphous, sexually dimorphic, or exhibit distinct developmental stages. But even plants without these features are unlikely to yield representative holotypes, if only because the author of a new species is often unfamiliar with the full range of variation within the species, just because it is new. ${ }^{22}$

From the standpoint of standard notions of typicality, as well as from that of earlier botanical practice, the status of the modern type specimen is therefore puzzling, even paradoxical. Under some philosophical constructions, the very term type specimen is an oxymoron. A specimen is one of

22. Sometimes two or more specimens are designated by the author of a species as its types; these are called syntypes. Specimens cited in the original publication but that are designated neither as the holotype nor as syntypes are known as paratypes (SLC, art. 9.4-5). 
those natural particulars Locke believed it was the office of language to subsume under general ideas, lest the understanding drown in detail: "Every Bird, and Beast Men saw; every Tree, and Plant, that affected the Senses, could not find a place in the most capacious Understanding." ${ }^{23}$ In contrast, a type is a one of those "Patterns or Forms"-whether its origins are Platonic metaphysics, Lockean experience, or Kantian epistemology-to which particular things are compared and sorted accordingly. A type specimen however need not be and, because of circumstances surrounding the identification of a new species, often is not typical of the species it instantiates, as the 1999 Saint Louis Code states explicitly: "The nomenclatural type is not necessarily the most typical or representative element of a taxon" (SLC, art. 7.2).

Yet even if it is not a type in the sense of a prototype or an archetype or even an abstraction, the type specimen instantiates a class of entities, a class that itself is the prototype of what is meant by a natural kind: the organic species. The defining characteristics of the entire species are laid down with reference to the type specimen, an individual plant chosen more or less at random-in most cases because it is among the first to be encountered by a botanist exploring a new locale. Botanists do not harbor any illusions that a random sample of one is likely to be a perfect microcosm of the species macrocosm, any more than statisticians would willingly trust inferences drawn on such a tiny sample. For centuries, botanists have been acutely aware of variability within a single plant species or even variety, of the "monsters" created by the horticulturalist's art, and of nature's own sports, lusus naturae (see $C B$, aphorism 310, p. 196, and $L$, p. 37 ). ${ }^{24}$ Darwinian theories of individual variation through mutation as the motor of evolution have only sharpened this awareness of individual deviations from the species norm. ${ }^{25}$ The type specimen is only accidentally, not essentially, a representative sample of the species.

How else could an individual be said to define a class? Type specimens turn the traditional logic of abstract ideas as the basis for the classification of particulars on its head, defy the canons of reliable sampling and inference, and are emphatically not prototypes or archetypes or anything else smacking of the Platonic. Nor are they triumphs of nominalism: individual plants represent species; they do not, so to speak, supplant them. These are not just the puzzles of post hoc philosophizing; they bedeviled the botanists

23. Locke, An Essay Concerning Human Understanding, 3.3.2, p. 409.

24. On the relationships between botanists and horticulturalists, see Abigail J. Lustig, "The

Creation and Uses of Horticulture in Britain and France in the Nineteenth Century" (Ph.D. diss., University of California, Berkeley, 1997).

25. See Charles Darwin, On the Origin of Species (1859; Cambridge, Mass., 1964), pp. 44-59. 
themselves as they attempted to find a way out of the crisis of synonymy in the late nineteenth century. Their previous use of descriptions, illustrations, and herbarium specimens to define species had centered around the very notions of typicality and practices of idealization later subverted by type specimens. The gap between old and new views of types and specimens measures the magnitude of the transformation wrought by fusing the two into a seemingly impossible hybrid, the type specimen.

\section{On the Origins of Species Names}

Wherefore the Botanist is distinguished from the layman by the fact that the former is able to give a name which fits one particular plant and not another, and which can be understood by anyone all the world over.

-Carlolus von Linnaeus, Critica botanica, aphorism 210, p. 1

Botanists are those who know how to name all plants. Linnaeus himself named thousands of them, but he used methods that by the early twentieth century appeared arbitrary and even reckless to the botanists who still reckoned his Species plantarum as the proper starting point of scientific botanical nomenclature. It was not so much the names themselves that offended later sensibilities, although eyebrows were raised over the propriety of, for example, naming a climbing plant after one Mr. Bannister because he had climbed mountains. ${ }^{26}$ But for the most part botanists writing a century or more after Linnaeus were content to keep the by then familiar Linnaean names, however obscure or downright silly: "Today such abuses are legitimated by a hundred years of usage" ( $L, \mathrm{p}$. 37). The problem for botanists after circa 1900 was rather that Linnaeus and other earlier botanists had failed to designate holotypes for their species; indeed, their whole way of working was squarely at odds with the precepts and practices of the type specimen. As one current project to assign holotypes retroactively to Linnaean species notes ruefully, Linnaeus used not just one but several herbarium specimens, plus descriptions and illustrations of earlier authors, and sometimes live plants for his descriptions: ${ }^{27}$ "Consequently, there is rarely any single type specimen in existence, and typification involves identifying each of these original elements, before a choice is made." ${ }^{28}$

26. See William Whewell, The Philosophy of the Inductive Sciences, 2 vols. (London, 1847), 1:508. On older plant names considered vulgar, see D. Gledhill, The Names of Plants (Cambridge, 1985), pp. $2-3$.

27. On Linnaeus's sources (specimens, illustrations, and descriptions), see Stern, "An Introduction to the Species Plantarum and Cognate Botanical Works of Carl Linnaeus," pp. 65-74. Linnaeus often changed diagnostic specific names he had used in earlier publications when a new specimen or illustration came to his attention; see ibid., p. 87 .

28. "Linnaean Data Base: Introduction and Historical Perspective," http://www.nhm.ac.uk/ botany/linnaean/Introduction.html. The project seeks to establish type species for those 30 
Methods that now provoke exasperation among botanists trying to connect a species name with a type specimen were for Linnaeus and his contemporaries a matter of professional pride. Eighteenth- and early nineteenthcentury naturalists would have condemned a colleague so rash as to pin the identity of a species to a single specimen if other materials were available. Because natural phenomena, flora and fauna very much included, exhibited considerable variability, naturalists worthy of the name based their species descriptions on as wide a range of specimens as possible. Only seasoned judgment based on broad experience could distinguish the genuinely characteristic in any given phenomenon.

These views were shared not only by the majority of eighteenth-century botanists but also by contemporary practitioners of other descriptive sciences, such as anatomy, conchology, entomology, anthropology, and geodesy. These were the sciences of the trained eye, accustomed by years of experience to distinguish the essential from the accidental, the normal from the pathological, the typical from the anomalous, the variable from the constant. In principle, this was just as much a problem for the observational astronomer as for the field naturalist. The astronomers who tracked comets with telescopes were plagued by observations that strayed from any smooth path-hence the habit, continued well into the nineteenth century, of discarding outliers. ${ }^{29}$ In the context of a mathematical theory of observational error, Pierre-Simon Laplace imagined underlying constant causes, like the universal law of gravitation, upon which were superimposed a swarm of variable causes, ranging from the quality of the scientific instrument to the incalculable perturbations due to three or more massive bodies. ${ }^{30}$ Although few naturalists followed Laplace in developing a metaphysics of variability, they concurred that their task was to extract the truths of nature from the welter of confusing appearances.

There is of course an audibly Platonic ring to the language of truth somehow underlying appearances, noumena undergirding phenomena. This

percent of Linnaean names still lacking them. See Stern, "An Introduction to the Species Plantarum and Cognate Botanical Works of Carl Linnaeus,” pp. 103-24, 125-34. Zoologist Ernst Mayr notes that Linnaeus never designated any type specimens for his zoological species either and warns that because it "was customary in several European museums in the first half of the nineteenth century to substitute 'new' type-specimens whenever the old ones became faded or were damaged by insect pests. ... Evidence from old types must be treated with extreme care and discrimination and never be used to upset stable nomenclature" (Ernst Mayr, Principles of Systematic Zoology [New York, 1969], p. 368).

29. See Zeno G. Swijtink, "The Objectification of Observation: Measurement and Statistical Methods in the Nineteenth Century," in The Probabilistic Revolution, ed. Lorenz Krüger, Daston, and Michael Heidelberger (Cambridge, Mass., 1987), pp. 261-85.

30. See Pierre-Simon Laplace, Essai philosophique sur les probabilités (1814), in Oeuvres complètes de Laplace, 14 vols. (Paris, 1878-1912), 7:xlviii-ix. 
language of hidden simplicity under manifest complexity was as well suited to the sciences of stars and crystals as to those of plants and insects. But naturalists need not have subscribed to a metaphysics of ideal forms or, indeed, any metaphysics at all to ground their practices. Theirs was a truth of synthetic perception, of the ability to detect a common form uniting many individual exemplars of a kind. Falsehood sprang from inexperience and unripe judgment - as when Linnaeus reproached the French botanist Joseph Tournefort for having needlessly multiplied species of flowers, "93 Tulips (where there is only one) and 63 Hyacinths (where there are but two)" ( $C B$, aphorism 259, p. 122). In his morphological and methodological writings Johann Wolfgang von Goethe called such truths "archetypes" or "pure phenomena": "There are, as I note especially in the fields in which I work, many empirical fragments, that one must throw away in order to hold fast to the pure, constant phenomenon. ... In order to represent it [the pure phenomenon] the human mind stabilizes the empirical vacillations, excludes the accidental, sunders the impure, develops the confused, discovers the unknown." ${ }^{31}$

What Goethe theorized, a myriad of less contemplative naturalists of the eighteenth and early nineteenth centuries practiced; they sought to condense and integrate a legion of individual impressions into a "true" representation, in both words and images, of the natural kind in question. The Göttingen anatomist Albrecht von Haller exclaimed over the variety of arteries, which defied uniform description or even comprehensive naming. Only the experience of dissecting many corpses could instruct the anatomist in what was typical for the "perfect" human body, what deviant. And even his own prodigious labors and patience had not sufficed to compare all the diverse branchings of the arteries in one body with those of others so as to eliminate the singular. ${ }^{32}$ In such cases, the judgment of the naturalist and the art of the illustrator lay in knowing what to omit from a woodcut or engraving, as well as from the description of the natural object in question. Linnaeus exhorted his fellow botanists to eliminate all variable aspects of plants, such as color, from both specific characters and illustrations: "How many volumes have you [other botanists] written of specific names taken from colour? What tons of copper have you destroyed in making unnecessary plates? What vast sums of money have you enticed fraudulently, as it appears, from other men's pockets, the purchasers to wit, on the strength of colour alone?" ( $C B$, aphorism 266, p. 139). According to Linnaeus, the 1994), 13:23-24.

32. See Albrecht von Haller, Icones anatomicae, 2 vols. (Göttingen, 1756), vol. 2, fasc. V, f. A2.r-v. 
satisfactory botanical illustration "represents the plant as it were in a mirror"-but a mirror that filtered out all features except "Number, Shape, Position, and Proportion" ( $C B$, aphorism 282, pp. 162, 161).

It was the rule for anatomists and naturalists to supervise their artists and engravers closely, so that naturalism-the depiction of an individual specimen in all its peculiarities, exactly as it appeared to the eye-did not overwhelm the realism of the type. The nineteenth-century historian of botany Lodolf Treviranus insisted on the responsibility of the scientist to monitor the artist in every detail: "The drawing must therefore not only give exactest expression to the outlines, but also the form and direction of the stem, joints, the location and direction of the hairs; it must especially represent the characteristic veins of the leaf, and therefore must never be made without the superintendence of a scientific expert." ${ }^{33}$ Matthias Jacob Schleiden, pioneer of botanical microscopy, was scathing in his criticisms of a colleague, Heinrich Friedrich Link, who had allowed his draughtsman to conduct observations "all alone"; the result was, according to Schleiden, drawings that confused the reader "through lots of false views [Anschauungen]." ${ }^{34}$ A definitive image in anatomy, botany, or entomology was not a naturalistic rendering of any individual, but a composite image based upon but not in any mechanical way composed from numerous observations of the same natural kind. Coeval artists and critics like Joshua Reynolds saw little difference between artist and naturalist in this respect: "Thus amongst the blades of grass or leaves of the same tree, though no two can be found exactly alike, the general form is invariable: a Naturalist, before he chose one as a sample, would examine many.... He selects as the Painter does, the most beautiful, that is, the most general form of nature." 35 The watercolor studies of leaf types ("corduta," "reniformia," "triloba," and so on) of celebrated botanical illustrator Franz Bauer, who spent most of his long career at Kew Gardens, bear witness to this generalizing impulse (fig. 3).

The "most general form of nature" did not necessarily commit the naturalist to any metaphysics of Platonic ideas or Aristotelian essences as the basis for organic species. On the contrary, the ways eighteenth- and early nineteenth-century botanists defined species and other higher taxa was, in the modern term, polythetic, that is, based on several traits common to many but not all members of the class, rather than on an essential trait shared by each and every one of them-a practice similar to Wittgenstein's notion of

33. Lodolf Treviranus, Die Anwendung des Holzschnittes zur bildlichen Darstellung von Pflanzen (1855; Utrecht, 1949), p. 2.

34. Matthias Jacob Schleiden, Die Botanik als induktive Wissenschaft (Leipzig, 1845), p. 105.

35. Joshua Reynolds, “To the Idler” (1759), Discourses, ed. Helen Zimmern (London, 1887), p. 280. 


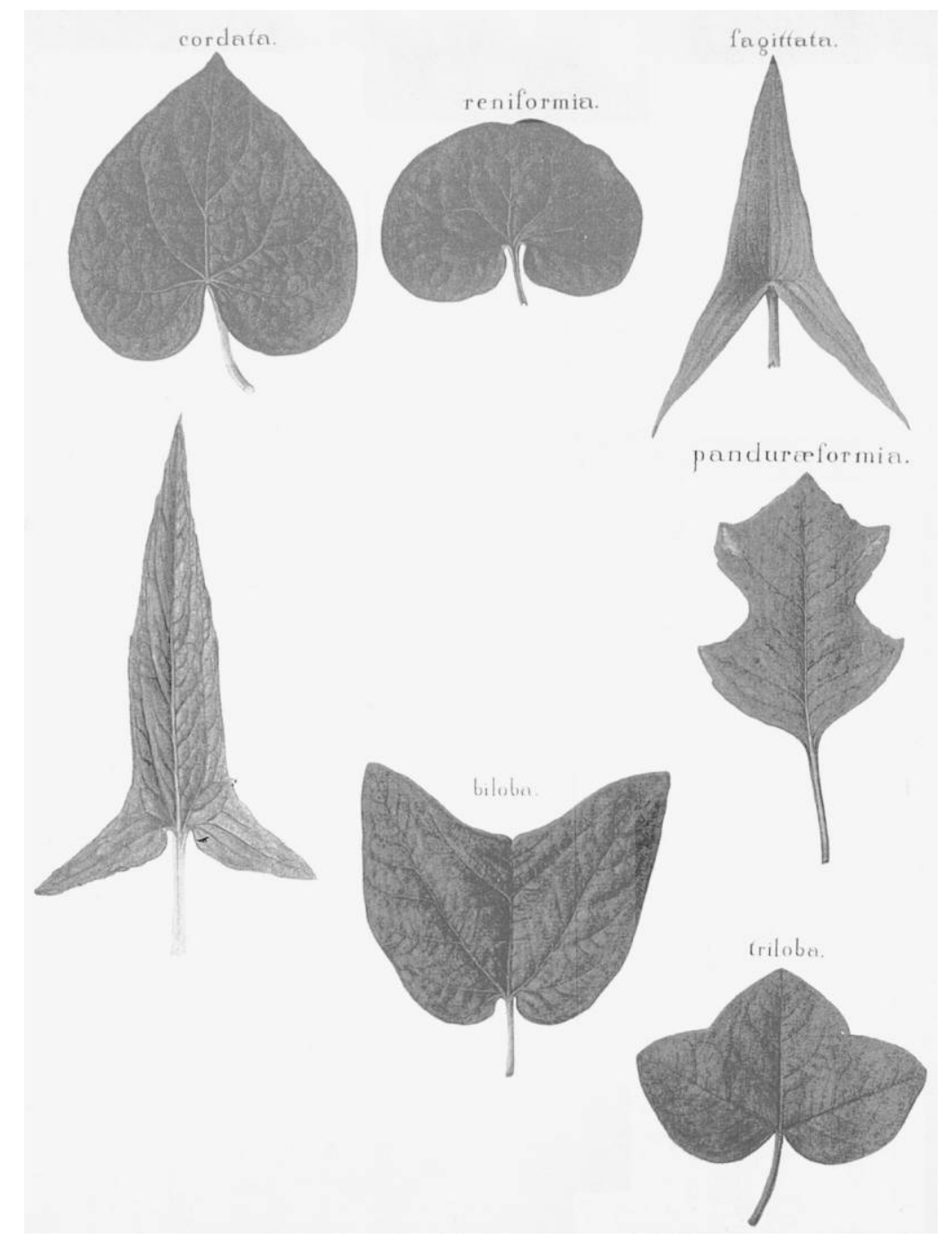

F I G U R E 3. Franz Bauer (1758-1840), Aquarelle of leaf types, Nachlass, Bd. VIII, p. 8. Courtesy of the Niedersächsische Staats- und Universitätsbibliothek Göttingen.

This content downloaded from 141.014.238.123 on April 15, 2019 01:46:13 AM 
definition by family resemblance. ${ }^{36}$ Within the context of botanical and zoological classification during this period, the word type was used in multiple senses, ranging from an exemplar that embodied the characteristics of a larger class (for example, a type species standing for a whole genus or a type genus for a family) to a morphological archetype or "Bauplan" underlying multiple taxa. ${ }^{37}$ So, for example, a particular herbarium specimen of Aster novae-angliae might be described as a prototype of the species, ${ }^{38}$ or the genus ardisia might be designated the "type of the new family of the Ardisiaceae." 39 Or a collection of color figures of plants drawn from life "as perfectly as possible" might be proposed as "types of the species" to be preserved for consultation at libraries and universities. ${ }^{40}$ At the other extreme, Harvard naturalist Louis Agassiz might claim that "every individual, though belonging to a distinct Species, is built upon a precise and definite plan which characterizes its Branch." ${ }^{41}$ Until the latter half of the nineteenth century, both the language and the practices of types in natural history admitted considerable variation.

But this range of variation did not include the possibility of an atypical type, as the term was then used. At every taxonomic level, a type could serve as the example of the next higher taxon (so an individual for a species, a species for a genus, a genus for a family, and so on) only if it were genuinely exemplary of the key features of the larger class. British physicist and philosopher of science William Whewell offered a lapidary definition of the type in natural history: "A Type is an example of any class, for instance, a species of a genus, which is considered as eminently possessing the characters of the class. ... The Type-species of every genus, the Type-genus of every family, is, then, one which possesses all the characters and properties of the genus in a marked and prominent manner." ${ }^{42}$ Whewell (who as master of Trinity College, Cambridge, was also concerned with scientific pedagogy) defended this definition by exemplification against the sneers of mathematicians who sought definition by essence, insisting that for this reason alone natural history deserved a place in the liberal education curric-

36. See Mary P. Winsor, “Non-essentialist Methods in Pre-Darwinian Taxonomy,” Biology and Philosophy 18 (June 2003): 391.

37. See Stevens, The Development of Biological Systematics, pp. 133-51, and Farber, "The TypeConcept in Zoology during the First Half of the Nineteenth Century."

38. See Stevens, The Development of Biological Systematics, p. 445 n. 4

39. Antoine-Laurent de Jussieu, "Note sur quelques genres anciens de plantes non classés antérieurement, et maintenant rapportés à leurs familles," Mémoires du Muséum d'Histoire Naturelle, no. 5 (1819): 247.

40. Auguste-Pyramus de Candolle [father of Alphonse de Candolle], Théorie élémentaire de la botanique (Paris, 1813), p. 287.

41. Louis Agassiz, Methods of Study in Natural History (1863; Boston, 1889), p. 139

42. Whewell, The Philosophy of the Inductive Sciences, 1:494-95. 
ulum. Examples forced students to look beyond books to things: "Its [natural history's] lesson is, that we must in all cases of doubt or obscurity refer, not to words or definitions, but to things." ${ }^{\text {43 }}$ Hence an individual specimen could serve as a type, but only on the basis of a careful selection on the basis of a thorough acquaintance with the species it was intended to exemplify, in turn the basis of the naturalist's synthetic judgment of the distinguishing marks of the species.

Yet by the time Whewell was writing in the 1840 os naturalists were engaged in a heated debate over the stability of names. As a result of voyages of exploration and colonial expeditions, collections of flora and fauna had swelled with new specimens, and with them the number of new species grew explosively. Whewell estimated that approximately ten thousand plant species had been known at the time of Linnaeus, compared to some sixty thousand circa $1845 .{ }^{44}$ At least as problematic as the proliferation of new species (and genera and families) to be named was the proliferation of naturalists doing the naming. British ornithologist Hugh Edwin Strickland, who launched a British Association for the Advancement of Science commission that in 1842 proposed rules for zoological nomenclature, warned against the danger of a cacophony of names as a result of too many naturalists in too many countries pursuing natural history in ignorance of one another and of names already designated. ${ }^{45}$ In a posthumous work based on some thirtytwo volumes of notes devoted to sorting out the recent avalanche of synonymy in ornithology, Strickland complained that sloth, finickiness, and scientific decentralization were to blame. Some naturalists "find some object exceedingly beautiful or curious; they cannot make it out, and do not like the trouble of inquiring for and examining the works that relate to it, and a new name is at once applied, which saves all further trouble to them." Or better-informed observers track down the original name but for some reason find it unsatisfactory and give the organism a new name. Still others "labour abroad, and have a large knowledge of their subject; but at a distance from all positive information," far from "the libraries or collections to illustrate even any one branch of Zoology or Botany." ${ }^{46}$ As a result, names multiplied, and science splintered.

43. Ibid., 2:372. See also Winsor, "Non-essentialist Methods in Pre-Darwinian Taxonomy," pp. 395-97.

44. See Whewell, The Philosophy of the Inductive Sciences, 1:507.

45. See Hugh Edwin Strickland, "On the Inexpediency of Altering Established Terms in Natural History" and "Report of a Committee Appointed 'To Consider the Rules by Which the

Nomenclature of Zoology May Be Established on a Uniform and Permanent Basis," Memoirs of

Hugh Edwin Strickland, ed. William Jardine (London, 1858), pp. 370-74, 375-97.

46. Strickland, Accipitres, vol. 1 of Ornithological Synonyms, ed. Mrs. Hugh E. Strickland and W. Jardine (London, 1855), pp. iv, v. 
Key to Strickland's and most subsequent proposals for the reform of natural history nomenclature were research collections of books and specimens. Because these were concentrated in capital cities and certain wellendowed universities, the necessity to consult them regularly effectively excluded local naturalists without institutional affiliation, an effect amplified by an insistence on retaining Linnaean Latin nomenclature. ${ }^{47}$ The number of visiting naturalists became an index of a collection's importance and power to dictate classification and naming procedures. ${ }^{48}$ But the stability of names required that naturalists in doubt about the novelty of a species consult not only the extant literature but also the specimens upon which the original publication had been based. The specimens were still usually multiple and preferably typical, but they were now explicitly made part of the reforms to stabilize names; hence Strickland regretted the breakup of collections and dispersal of specimens that were to serve as the future bulwarks against synonymy. ${ }^{49}$ Type specimens had been shifted to the center of nomenclature practices, but they remained exemplary.

The practices associated with exemplary type specimens-consulting as many specimens as possible in order to ascertain the range of variation in a species and thereby identify the most characteristic type-were still held up as the disciplinary standard when botanists, following the zoologists' lead, published their own rules in an attempt to halt the steep increase in synonymy. Alphonse de Candolle, who had been charged by the 1867 Paris International Botanical Congress with drafting a code of nomenclature, reminded his colleagues that rules alone would be ineffective to stem the tide of superfluous names if not backed up by approved practice: "Some botanists will continue to lack the materials for good work, the ways of conceiving species will vary for a long time, and there will always be few authors who will take the trouble to study all the forms of a species, all the species of a genus, in the principal herbaria of Europe, which is indispensable to avoid errors" ( $L$, p. 10). Without firsthand study of all relevant herbarium specimens, the characteristics of species could not be defined with confidence, inviting the multiplication of names for the same taxonomical entity.

47. On the social and political dimensions of Strickland's complaints and recommendations, see Gordon R. McOuat, "Species, Rules, and Meaning: The Politics of Language and the Ends of Definitions in Nineteenth-Century Natural History," Studies in History and Philosophy of Science 27 (Dec. 1996): 473-519.

48. Noting that between 1840 and 1850 , over four hundred naturalists visited the zoological department of the British Museum, historian of science Gordon McOuat argues that through "the absolute bulk of its 'fixed capital' of naturalist goods, the Museum could set its own tacit rules for naturalist discourse" (McOuat, "Cataloguing Power: Delineating 'Competent Naturalists' and the Meaning of Species in the British Museum," British Journal for the History of Science 34 [2001]: 7). 49. See Strickland, Accipitres, p. x. 
Nonetheless, Candolle and the International Botanical Congress hoped that a strict law of priority of publication would clear up some of the nomenclatural confusion. The only valid name of a "natural group of plants" was to be that first published-by Linnaeus himself or by a publication that conformed to the binomial Latin forms laid down by Linnaeus. Publication covered a multitude of possibilities of varying degrees of publicity, from printed articles and figures to labels affixed to herbarium specimens. Candolle emphasized that the publication of the name was "the essential fact, for it is the one which prevents changing the name, except for weighty reasons. He who publishes has enacted the principal deed" ( $L$, pp. 17 [art. 15], 24 [art. 41], 53 [art. 50]). Subsequent revisions of the code of botanical nomenclature would strengthen the priority rule, whittling away Candolle's "weighty reasons" to make it ever more difficult to change a name once given. The zoologists also underscored the primacy of publication in their nomenclatural edicts. The Société Zoologique de France defended the "law of priority" on the grounds that "knowledge of organisms accumulated by the continuous labor of humanity would not have been transmissible except on the condition that each one of these beings had a name known to everyone." Although the society did not recommend sanctions for those who defied the law, it warned that the dangers of doing so would be taught in the hard school of experience..$^{50}$

At stake in the regulation of names in natural history was the transmission of knowledge and the coherence of a community of knowers. As in the story of Babel, these challenges meshed closely with one another. Without a common language, human beings could not cooperate to build the tower; without a shared nomenclature, the collective empiricism of natural history, dependent on a large and dispersed network of inquirers to investigate nature's organic variety, crumbled like the tower. Late nineteenth-centurybotanists, especially those at the periphery of the scientific network, recognized that changes in the social organization of their discipline had exacerbated synonymy. American naturalist Lester Ward defended the law of priority as a simple matter of restoring orphaned plants that "have strayed, as it were, from home, been lost, adopted by strange persons, and given different names" to their "true parentage." He explained that such problems had become pressing with the greater number of botanists, less deferential to a few authorities at European centers of research: "Formerly there was one high seat from which the botanical decrees emanated, and there was far less danger that unreasonable things would be done by one or two persons than

50. Société Zoologique de France, De la nomenclature des êtres organisés (Paris, 1881), p. 23; see also p. 36. The zoologists took a stricter view of publication than Candolle had, ruling out anything but print; see p. 29. 
by many." ${ }_{51}$ His colleague and countryman O. F. Cook took a dimmer view of past botanical oligarchies, ruled from institutions like Kew Gardens in London or the Muséum Nationale d'Histoire Naturelle, with their impressive collections. It was high time in his opinion that botany had become decentralized and thereby democratized: "Though this fact has been deplored, especially by those who enjoyed a more or less complete monopoly of opportunity, it must be admitted that scientific study is one of the natural rights of man about which no artificial barriers can be maintained." ${ }^{2}$ Even Candolle, precisely the sort of European princeling of the discipline Cook hoped to dethrone, acknowledged that no modern botanist, however powerful and respected, was in a position to dictate to colleagues as Linnaeus had once done ex cathedra from Uppsala. ${ }^{53}$

Yet Cook admitted that opening up the botanical community had unleashed the curse of synonymy. Specialists no longer enjoyed the authority to enforce names once and for all on a resistant "scientific public." Some standard was needed to transfer authority from persons to nature and glue names permanently and unambiguously to things. Largely at the initiative of American botanists, painfully conscious of their distance from the great European herbaria and libraries that had undergirded the judgments of naturalists able to consult them regularly, proposals to supplement the law of priority by the type method gathered steam in the 1890 os and thereafter. Proposals to so amend the 1867 Paris Code were submitted in successive codes now named for American cities like Rochester (1893) and Philadelphia (1904). At the heart of these proposals was the type specimen, as the substantial model for all other types of higher taxa (such as the type species of a genus). Marching with this movement, Cook recommended that names and species be defined by the type specimen, "the first individual to which the name was applied constituting the type of the species" ("MT," p. 481).

A flurry of articles, mostly in American scientific journals, in the years around 1900 struggled with the implications of the newly adopted principle of the type specimen for botanical practice. ${ }^{54}$ Suddenly, a type specimen was no longer one herbarium sample among many but "the most important material in a museum of natural history." ${ }_{55}$ Its preservation, its where-

51. Lester F. Ward, “The Nomenclature Question,” Bulletin of the Torrey Botanical Club 22, no. 7 (1895): 309, 316.

52. O. F. Cook, "The Method of Types in Botanical Nomenclature," Science, n.s., 12, no. 300 (1900): 476; hereafter abbreviated "MT."

53. See Alphonse de Candolle, La Phytographie, p. 242.

54. The fourth fundamental principle of the 1904 Philadelphia Code (formulated as a set of recommendations to the 1905 International Botanical Congress in Vienna) states that "the application of a name is determined by reference to its nomenclatorial type" ("Code of Botanical Nomenclature," Bulletin of the Torrey Botanical Club 31 [1904]: 251; see esp. canon 14, p. 254).

55. Schuchert, "What Is a Type in Natural History?" p. 636. 
abouts, its very existence became matters of urgent interest to naturalists. Botanists were advised to label type specimens clearly and construct special glass-fronted cases for them, ${ }^{56}$ to compile catalogues listing their locations in various collections, ${ }^{57}$ and, above all, to designate them if the original authors had not, as was all too often the case for species published in earlier periods. ${ }^{58}$ The law of priority had forced botanists to become scrupulous bibliographers, tracking down the original publication in order to verify descriptions and names; the method of type specimens plunged them into manuscript research. In the absence of a designated type specimen, it "then becomes necessary to consult the author's herbarium or the herbarium in which his plants are deposited. Specimens which bear the name in his handwriting should be given preference in the selection, and of these the type is the one from the locality first mentioned, or the one collected by the person for whom the species is named." ${ }^{59}$ The fortunes of personal collections containing types now mattered: had they been donated to a museum? sold to another private collector, and if so to whom? lost in a fire or by some other accident? "Audubon, J.T. His liby. destroyed by fire”; "Cuvier, G. \& Valenciennes. Fishes in Paris but types often replaced"; "Calvert, John.... He was an unscrupulous blackguard. He seduced two of the Sowerby girls [daughters of British botanist and illustrator James Sowerby].... Of this coll. the B.M. [British Museum] bought a few in 1866, some of which were labelled by James Sowerby, but it is doubtful if any were types or figured." 60 The biographies of type specimens had become as important as those of their authors to botanists intent on nailing a name to a species.

The new practices of the type specimen compelled botanists to abandon the old practices of figures and descriptions derived from numerous specimens. ${ }^{61}$ Article after article weighed the pros and cons of multiple versus unique type specimens, but most plumped for singular specimens as the only way to insure the singularity of species names, despite the difficulties entailed by applying this rule to polymorphous plants or to fragmentary

56. See ibid., p. 639; C. Hart Merriam, “Type Specimens in Natural History,” Science, n.s., 5, no. 127 (1897): 731-32; and Maude Kellerman, "A Method of Preserving Type Specimens," Journal of the Washington Academy of Sciences 2 (Jan. 1912): 222-23.

57. See for example Schuchert et al., Catalogue of the Type Specimens of Fossil Invertebrates in the Department of Geology, United States National Museum, pt. 1 of Catalogue of the Type and Figured Specimens of Fossils, Minerals, Rocks, and Ores in the Department of Geology, United States National Museum, ed. George P. Merrill (Washington, D.C., 1905), and Charles Davies Sherborn, Where Is the Collection? (Cambridge, 1940).

58. See A. S. Hitchcock, "Nomenclatorial Type Specimens of Plant Species," Science, n.s., 21, no. 543 (1905): 828-32.

59. Ibid., p. 829.

60. Sherborn, Where Is the Collection? pp. 11, 41, 29.

61. For the persistence of these older practices in zoology, see Farber, "The Type-Concept in Zoology during the First Half of the Nineteenth Century," p. 190. 
fossils. ${ }^{62}$ The holotype was "the only specimen possessed by the nomenclator at the time; the one specimen definitely selected or indicated by the nomenclator as the type; the one specimen which is the basis for a given or cited photograph." ${ }^{63}$ Hence the type of the species was typically no longer typical. This consequence of new nomenclatural rules based on the type method was so counterintuitive to most botanists that it had to be repeated and underscored and eventually explicitly stated in codes. Some botanists proposed that a new kind of type, the norm, be introduced as "a composite portrait of the species." But it was clear to them that they would not be able to reclaim the word type for the truly typical specimen: "For this kind of type, far removed from a type-specimen, we want a name; and as the word type has been stolen from us it will save confusion to avoid it altogether." 64

The proponents of the new type method of botanical nomenclature deliberately avoided ontological commitments as to whether higher (supraspecies) taxa were real or conventional or even to a firm definition of species. Their definitions of species were notably minimalist: "For nomenclatorial purposes a species is a group of individuals which has been designated by a scientific (preferably a Latin adjective) name, the first individual to which the name was applied constituting the type of the species" ("MT," p. 481). Whether this group was understood in essentialist or nominalist or Darwinian terms was left open. In some quarters, the type method was advanced as an antidote to all metaphysics, as a genuinely "inductive" alternative. Indeed, the aim of the proposed amendments to first the Paris Code of 1867 and later the Vienna Code of 1905 was to protect the stability of names against any future changes in classificatory systems. ${ }^{65}$

The type method provoked stiff resistance that lasted for decades, especially from European botanists who balked at the mechanical application of its rules. ${ }^{66}$ Americans for their part claimed that the vaunted personal discretion of their Old World colleagues was merely a euphemism for the "personal equations" in assigning names ("MT," p. 478). Although the 1905 Vienna International Botanical Congress rejected the recommendations of the "American Code," the principle of the type method was accepted by the

62. See Schuchert, "What Is a Type in Natural History?" p. 637. See also Merriam, "Type Specimens in Natural History," p. 732; Swingle, "Types of Species in Botanical Taxonomy," p. 864; and Schuchert, "Catalogue," p. 10.

63. Schuchert and S. S. Buckman, "The Nomenclature of Types in Natural History," Science, n.s., 21, no. 545 (1905): 900.

64. F. A. Bather, "A Postscript on the Terminology of Types," Science, n.s., 5, no. 126 (1897): 844; compare Candolle, La Phytographie, p. 51n, concerning the distinction between an échantillon authentique and an échantillon typique.

65. See Cook, "The Method of Types," Science, n.s., 8, no. 198 (1898): 514.

66. See Hitchcock, "The Type Concept in Systematic Botany," American Journal of Botany 8 (May 1921): 252-53. 
Brussels International Botanical Congress in 1910. In the most recent codes (Tokyo 1994, Saint Louis 1999), it is enshrined as a fundamental principle; its practices are correspondingly entrenched. Theories and a fortiori metaphysics might come and go, but names and the unique type specimens that bore them would endure. Botanists once more had a common language, albeit one purchased at the price of paradox, an atypical type.

\section{So Careful of the Type}

If virtue \& friendship have not yet become fables, do believe we keep your face for the living type.

$$
\text { —Ralph Waldo Emerson to Thomas Carlyle }{ }^{67}
$$

What does it mean for a type to have a face? Not just the idealized, marble face of an allegory of virtue and friendship, but that of a concrete individual? Type specimens are no longer living, but they are as individual and concrete as Carlyle was to his friend Emerson. Yet they have not been selected as Emerson chose Carlyle, as the most perfect and characteristic expression of the virtues he wished to embody. The procedure is instead more in the spirit of Walt Whitman, as if a random individual had been plucked from the crowd of citizens to be decked out in the chiton and emblemata of Virtue and Friendship, the words made flesh by lottery.

There is no fiction that all individual members of a botanical species are so much alike as to be interchangeable; on the contrary, Darwinists, for example, scrutinize individual variations, "hopeful monsters," as the raw material on which natural selection works. And of course according to evolutionary theory the species themselves are time-bound entities, in slow but steady flux. But neither are botanical species mere amalgamations of just any individuals; there are strict criteria for membership that take years of fieldwork and hard study of systematics to master. It is not a matter of indifference to botanists as to whether any given plant is assigned to one species or another. And it is a matter of the utmost importance that names remain attached securely to species, however much classification systems or even the species themselves may change. The type specimen is the facethe dessicated, flattened face to be sure, but still the face-that is attached to the name of a species, and on the permanence of that relationship depends the transmission of botanical knowledge amassed for centuries.

Philosophers have remarked on the curious referential properties of type specimens, pointing out their resemblance to what Hilary Putnam and Saul Kripke called rigid designators-names assigned to a natural kind that are

67. Ralph Waldo Emerson, letter to Thomas Carlyle, 7 Oct. 1835, in Other People's Mail: Letters of Men and Women of Letters, ed. Lola L. Szladits (New York, 1973), p. 33. 
preserved by a continuous lineage of reference, despite changes in the meaning of the name. So, for example, the name water remains attached to the natural kind water despite numerous changes in ideas about the composition of water; the water pre-Socratic philosopher Thales believed to be the fundamental component of the universe is the same as the water now understood as a composition of hydrogen and oxygen. ${ }^{68}$ Names inhere rigidly in their referents, regardless of the truth of descriptions. Philosophers of biology have interpreted the way naturalists use type specimens in this light; some have suggested that sense can be made of these practices by conceiving of the entire species as an individual, albeit as a temporally and spatially dispersed one, and hence by regarding the type specimen as a part of this species-individual, just as a feather is a part of bird or a hoof is a part of a horse. To define a species by means of a type specimen would therefore be a kind of definition by ostension, by singling out, as Alex Levine puts it, "a conveniently sized and packaged part of a species, a suitable target for the act of ostension in which the species acquires its name." ${ }_{69}$

There are certainly analogies between the aims of rigid designators in the theory of reference and those of type specimens in botanical nomenclature. Both are meant to preserve the relationship between names and things as knowledge about what the things really are changes over time. But there are also striking disanalogies. If type specimens are just parts of the speciesindividual that can be pointed out to define the (from the standpoint of human perception) scattered species-individual, why insist upon the singularity of the holotype? Why aren't more parts better than one, as they surely would be if one were trying to reconstruct an organism from, for example, fragmentary and dispersed fossil remains? Moreover, in contrast to rigid designators, botanical type specimens are not independent of the truth of the description of the species they instantiate. Once a natural kind has been baptized as water, name and natural kind stick together whether the natural kind is understood as one of the Aristotelian four elements, heavier than air but lighter than earth, or as $\mathrm{H}_{2} \mathrm{O}$. Similarly, if a species is transferred to another genus, its type specimen does indeed travel with it (under the new name). But if a species description clearly disagrees with

68. See Hilary Putnam, "The Meaning of Meaning," in Language, Mind, and Knowledge, ed. K. Gunderson (Minneapolis, 1975); Saul Kripke, Naming and Necessity (Cambridge, Mass., 1980); and Scott Soames, Beyond Rigidity: The Unfinished Semantic Agenda of Naming and Necessity (Oxford, 2002).

69. Alex Levine, "Individualism, Type Specimens, and the Scrutability of Species Membership," Biology and Philosophy 16 (June 2001):327-28. See also David L. Hull, "Exemplars and Scientific Change," PSA 1982, ed. Peter D. Asquith and Thomas Nickles, 2 vols. (East Lansing, Mich., 1983), 2:491-92. 
the type specimen, the description trumps, and names are applied accordingly (see SLC, art. 7.4). Finally, the relationship between rigid designator and the natural kind it names is bipartite; there is no equivalent of the unique, individual type specimen to mediate between name and thing. There is, to continue with the example of water, no designated brook or sea that serves as the sole holotype of that natural kind.

The work done by the type specimen seems, rather, to resemble that done in political theory by elected representatives. It is an all-too-familiar fact that political representatives do not always represent their constituencies, either in the sense of resembling most of the voters in any socioeconomically or ideologically significant way or in carrying out their political wishes. As in the case of individual members of a botanical species, individual members of a constituency are not identical to one another and vary along many different dimensions. And yet one such concrete individual must represent the whole, in botany as in politics. Some political theorists have openly doubted whether such representation is possible. Rousseau famously criticized polities in which an overweening concern for commerce and comfort led citizens to delegate their military duties to mercenaries and their political duties to deputies in a national assembly. Only a legislative assembly composed of all citizens enjoyed true sovereignty: "Sovereignty cannot be represented, for the same reason that it cannot be alienated; its essence is the general will, and will cannot be represented - either it is the general will or it is something else; there is no intermediate possibility." ${ }^{70}$ Political theory from the seventeenth century on, whether absolutist or republican, is littered with attempts to fuse the populace into its single, concrete, legitimate representative, as in the frontispiece to Thomas Hobbes's Leviathan (1651), a picture of a crowned monarch whose gigantic body is composed of those of his subjects (fig. 4). Whether the entity to be represented is conceived as having an essence-be it the general will or the species ideal type-or as just a motley multitude, attempts to put a single face to a large group soon strain the imagination.

The title by which a type specimen represents but does not exemplify its species ultimately rests upon the scientific practices by which it does so, just as the claim of members of a legislature to represent their constituency stands or falls by their political practices. The type specimen is not just the bearer of the species name; it is in principle the original of the species description (and botanists take considerable pains to make sure this is so, so that long, tortuous bibliographic chains sometimes connect species and

70. Rousseau, The Social Contract, trans. Maurice Cranston (1762; Harmondsworth, 1968), 3.15, p. 141. 


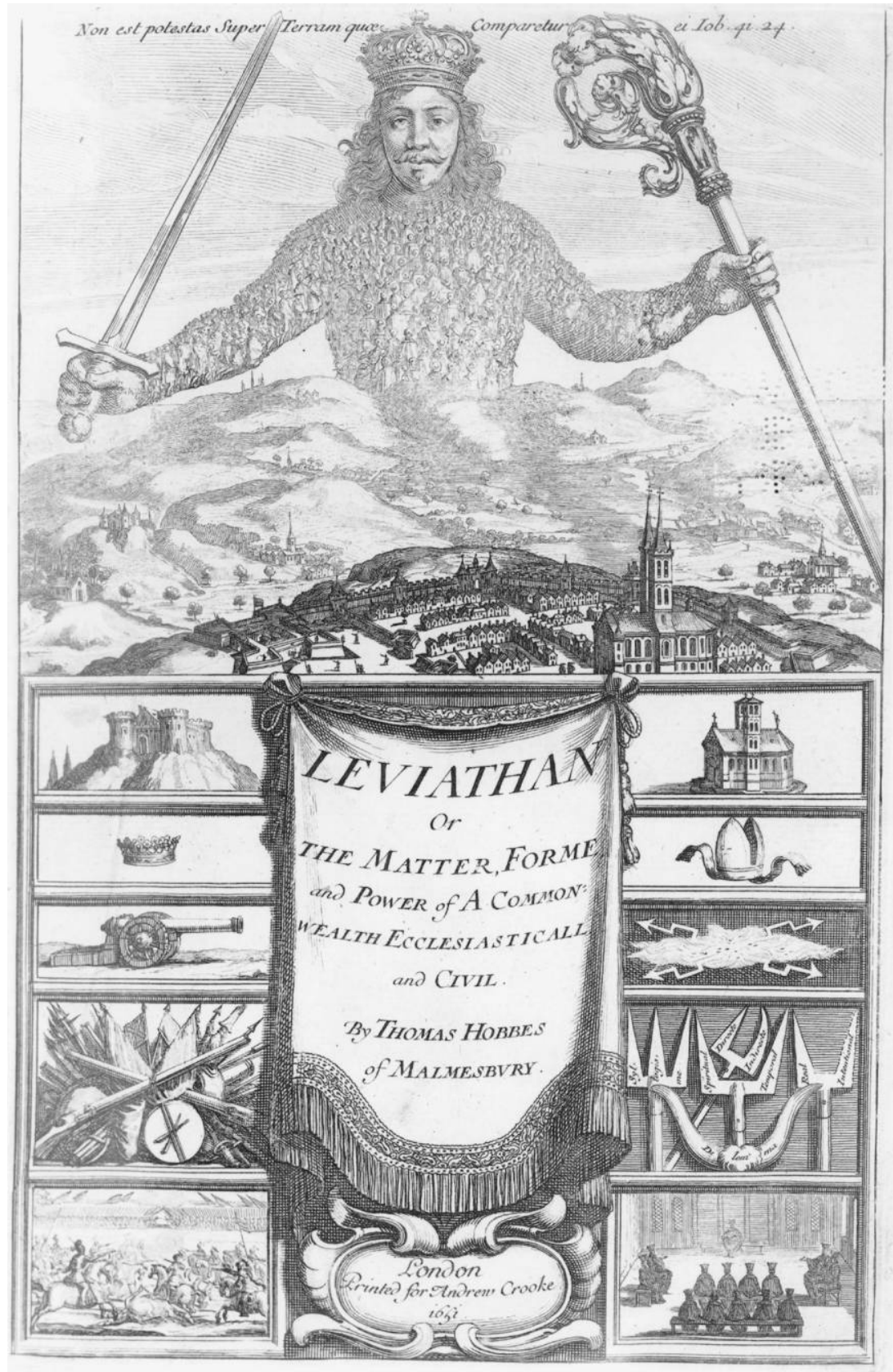

F I G U R E 4. Frontispiece of Thomas Hobbes, Leviathan, or The Matter, Forme, and Power of a Common-Wealth Ecclesiasticall and Civill (London: Andrew Crooke, 1651). Courtesy of Rare Books Division, the New York Public Library, Astor, Lenox, and Tilden Foundations. 
type)..$^{71}$ This is why botanists must know not only that a type specimen exists but also where it exists, in case it must be consulted. To compose a monograph on a botanical taxon or to unsnarl a classificatory tangle requires firsthand inspection of the holotype, if possible. Recent internet projects to create databases of "E-Types" aim to reduce the inconvenience of travel to collections and to make holotypes accessible to naturalists worldwide..$^{72} \mathrm{~A}$ type specimen must at least be seen, whether on the herbarium page or in a high-resolution digital photograph.

It is by comparison of particulars with particulars, not of particulars with universals, or of the concrete exemplum with the abstract idea, that botanists ascertain species boundaries and species membership. To describe such methods as polythetic and to liken them to the detection of Wittgensteinian family resemblances is correct, but somewhat misleading. Instead of surveying a group portrait for family resemblances, botanists focus on one individual member, the holotype, side by side with its description, as the standard against which other specimens are measured. What botanists thereby perform is not so much an induction over particulars as one between particulars. If the species is a kind of generalization, a kind of plant Leviathan, it is not one composed by the enumeration of interchangeable individuals, as a census counts up residents of a country. It is more like a wheel of comparisons, each a point along the hub representing an individual specimen connected along a spoke to the type specimen at the center, as well as connected to one another by relationships of resemblance. (Such a wheel contrasts with the Venn diagram cluster of variously overlapping sets that would represent family resemblances, although neither structure corresponds to an essential definition of traits shared by each and every member of the species.) It is the trained eye and judgment of the botanist that discerns these connections, shuttling back and forth among holotype, description, and other specimens.

These are the practices that chain names to species via type specimens. An act of baptism in which the species is given a name does not suffice. Nor does simple ostension, a finger pointed at that designated specimen as a

\footnotetext{
71. For example:

Echium lycopsis L. (Fl. Angl.: 12. 1754) was published without a description or diagnosis but with reference to [seventeenth-century English botanist John] Ray (Syn. Meth. Stirp. Brit., ed. 3:227. 1724), in which a "Lycopsis" species was discussed with no description or diagnosis but with citation of earlier references, including [sixteenth-century Swiss botanist Gaspard] Bauhin (Pinax: 255. 1623). The accepted validating description of E. lycopsis is that of Bauhin, and the type must be chosen from the context of his work... The first acceptable choice is that of the illustration, cited by both Ray and Bauhin, of "Echii altera species" in [sixteenthcentury Flemish botanist Rembert] Dodonaeus (Stirp. Hist. Pempt.: 620. 1583). [SLC, art. 7.7] 72. See “The E-Type Initiative," http://140.247.119.145/Etypes/About.htm
} 
synecdoche for its species. It is the calibration of species-always incorporated in particular specimens-with the holotype and description that forges the chain of transmission. This is neither realism-botanical species as essences-nor nominalism-species as random agglomerations of individuals. It is equally difficult to locate along the axis running from concrete to abstract. The holotype and its practices of induction between particulars have created a new way of representing the many by the one, a particular that stands in for the species, a type incarnate in the individual. Metaphysics in action.

Everyone can now take part in the applied metaphysics of designating type specimens. The website of the ALL Species Foundation (based at the California Academy of Sciences in San Francisco) recruits volunteers to help taxonomists finish "the complete inventory of all species of life on Earth within the next twenty-five years-a human generation." The world's approximately ten thousand taxonomists will need "an army of apprentices, or parataxonomists, to assist in the initial inventory efforts and sorting of specimens" in their locales; detailed images of type specimens will be collected in online databases. The parataxonomists and the databases will spare the taxonomists arduous travel to remote field sites and museums. Since Linnaeus, circa 1.7 million species have been identified; estimates on the species remaining to be discovered range from 10 to 100 million. But the project's backers are optimistic; E. O. Wilson, entomologist at Harvard University's Museum of Comparative Zoology, believes that new technologies such as digitalized images of specimens "can speed up the exploration, description, and analysis of the world's biodiversity by as much as 100-fold." ${ }^{73}$ Work on the tower in the plain of Shinar has begun anew.

73. Quoted in FAQ, “ALL Species Foundation,” http://www.all-species.org 